\title{
Power-sharing in Africa's war zones: how important is the local level?*
}

\author{
Claudia Simons \\ Stiftung Wissenschaft und Politik, German Institute for International \\ and Security Affairs, Research division Middle East and Africa, \\ Ludwigkirchplatz 3-4, I07I9 Berlin, Germany \\ Email: claudia.simons@swp-berlin.org
}

FrANZISCA ZANKER

Email: franzisca.zanker@giga-hamburg.de

Andreas Mehler

Email: andreas.mehler@giga-hamburg.de

and

Denis M. Tull

Email: denis.tull@swp-berlin.org

A B S T R A C T

Research on power-sharing in Africa remains silent on the effects of national peace agreements on the sub-national level. Conversely, most armed conflicts originate and are fought in (or over) specific areas. A plausible hypothesis would be that for power-sharing to have the desired pacifying effect throughout the national territory, it needs to be extended to the local level. Based on fieldwork in six former hotspots in Liberia, Burundi and the Democratic Republic of Congo (DRC) we find that there is hardly any local content, including local power-sharing, in national agreements. However, contrary to

* This research was funded by the German Research Foundation (DFG) within the Priority Programme 1448 'Adaptation and Creativity in Africa'. An earlier version of this paper was presented at the African Studies Association 55th Annual Meeting, Philadelphia, December 2012. We thank the editors and two anonymous reviewers for their comments. All errors remain our own. 
our hypothesis, neither local content (inclusion of actors or interest) nor localpower-sharing (either introducing a local power balance or monopoly) are indispensable to effectively bring about local peace, at least in the short-term. On the contrary, it might even endanger the peace process. The importance of the sub-national level is overestimated in some cases and romanticised in others. However, the history of spatial-political links, centralised policies, and the establishment of local balances or monopolies of power ultimately play an important role.

Since the 1990s, the international community has significantly expanded its efforts to end internal wars in Africa. In most cases, these efforts have involved peace agreements between insurgent groups and incumbent leaders, often resulting in temporary power-sharing governments of national unity. No fewer than 18 out of 19 peace accords signed between 1999 and 2007 in Africa stipulated some form of powersharing between incumbent leaders and rebel groups to end civil war and restore political order (Mehler 2009). Recently, the practice has also been extended to countries affected by election-related violence, i.e. Kenya and Zimbabwe. This empirical trend has been followed by researchers, who have questioned whether power-sharing is an effective tool of conflict management and whether its growing popularity is justified by the results (Hartzell \& Hoddie 2003, 2007; Roeder \& Rothchild 2005; Tull \& Mehler 2005; Pearson et al. 2006; Sriram 2008; Mehler 2009). Although this emerging body of work has enhanced our understanding of power-sharing in itself, there is no consensus on its overall effects on peace (for a summary see Williams 2011; see also Lemarchand 2007). Most qualitative oriented research appears to be sceptical about the peace-promoting effects of power-sharing, including its unintended consequences (Roeder \& Rothchild 2005; Tull \& Mehler 2005; Pearson et al. 2006; Sriram 2008; Mehler 2009). Conversely, most quantitative studies tend to conclude that power-sharing provisions foster post-war peace (Hoddie \& Hartzell 2005; Jarstad \& Nilsson 2008).

By and large, both qualitative and quantitative research about powersharing remains focused on the national, aggregate level. However, there are good reasons to consider the local level to understand the dynamics of peace in post-conflict settings. We define 'the local', or 'local arena' as we call it, as territorial and administrative units outside the capital and below national state institutions, that is, the sub-national level. In our case studies this refers to urban provincial/county capitals (Goma and Bukavu in the Democratic Republic of Congo (DRC), Ganta and Gbarnga in Liberia, Gitega and Bubanza in Burundi), as well as rural areas (Kalehe and Sake in the DRC, the rural areas around 
Gitega and Bubanza in Burundi). The choice of districts and smaller provinces is random, but only to an extent, in that we sought to select units of analysis that are large enough to be of potential political significance vis-à-vis the national but small enough to enable us to identify relevant local actors, their interests and interactions, allowing us to establish links between local places, actors and interests. We acknowledge that both actors and concerns on local and national levels are interlinked in manifold ways. Furthermore, the multi-scalar nature of the conflicts in the DRC, Burundi and Liberia, and the divergent territorial configuration of the three countries should guard us against unduly generalising about diverse conceptions of the local. We understand local interests and concerns as those of local power holders, which can be at odds with the concerns of the broader population or other powerful local actors.

Why should the local level matter for the success or failure of a peace process? Violence and conflict do not hit a country evenly. In most armed conflicts there are hotspots in specific areas, which should be considered when evaluating the effect of power-sharing. In some cases national peace is restored as a result of an agreement, whilst conflict or insecurity continues in these local hotspots. There are three interrelated reasons for this. First, national peace agreements often fail to address local causes of conflict. This implies, second, that the interests of local actors are excluded. This has an impact on conflict dynamics, especially when these actors are able to mobilise violence in defence of their interests. Third, actors agreeing on peace at the national level might not represent cohesive organisations, and thus may not be able to effectively control their local followers. When the latter do not find their interests taken into consideration by their leaders turned ministers, generals etc., they may continue to fight, derailing the peace process. Consequently, it is arguable that the inclusion of local actors and interests in national power-sharing agreements - broadly conceived as 'local content' or the extension of power-sharing to the local level (local power-sharing) - contributes to sustainable peace.

Looking at six case studies of local arenas (i.e. former hotspots) in three countries (Liberia, Burundi, DRC) we find, perhaps surprisingly, hardly any local content (of either actors or concerns) in national power-sharing agreements whilst outcomes of local power-sharing are uneven. However, we suggest that contrary to our hypothesis, the involvement of the local, in terms of local content or local power-sharing, is not a necessary condition for national power-sharing to effectively bring about local peace. On the contrary, local power-sharing might even endanger peace processes. We conclude that the importance of the 
sub-national level tends to be overestimated in some cases - at least in the short-term - and romanticised as an ever-effective device in others. Eventually other context conditions will determine what effect local power-sharing will have.

THE IMPORTANCE OF THE LOCAL LEVEL

Agreement among the elites of warring factions is a necessary condition for peace. Power-sharing accords may enable this, insofar as every faction gains access to power and resources, providing an effective incentive to stop fighting. But it may not be a sufficient condition. Power-sharing agreements do not automatically imply that peace, agreed upon by a narrow circle of elites in the capital, trickles down to the rest of the country. National peace (negatively defined) is sometimes cited as achieved, even though violence persists in the hinterlands. Moreover, most armed conflicts are not territorially uniform phenomena. They originate and are fought in (or over) specific areas. Local interests and concerns are often the basis of mobilisation (Fearon \& Laitin 2003).

An extreme and prominent case of this decoupling of national and local peace is the DRC. After years of civil war, the power-sharing agreement of 2003 quickly unfolded positive results on the national level. The principal leaders of warring factions took up positions in the central government and other state institutions. However, in the eastern provinces of North and South Kivu, armed conflict remained pervasive. To this day, militias and rebel groups continue to fight each other and the government army. Meanwhile, following the 2006 'post-conflict' elections, donors and international organisations have continued to describe the DRC as a 'post-conflict' country, ignoring the continuation of armed conflict in an important part of the country (Autesserre 2010).

The DRC illustrates the importance of looking beyond the macropolitical level and its national players in order to explore the process and consequences of power-sharing on the sub-national level. This idea mirrors research arguing that among the various core dimensions of power-sharing, territorial power-sharing - accords over territorial autonomy for regions and provinces - is a more powerful mechanism to secure peace than political or economic power-sharing (Hoddie \& Hartzell 2005; Jarstad \& Nilsson 2008; but see Lake \& Rothchild 2005). The supposed effectiveness of territorial power-sharing points to the relevance of sub-national dynamics for transitions from war to peace. 
We propose three interrelated arguments to explain why elite pacts do not necessarily imply the end of hostilities in the hinterlands.

First, most elite pacts do not address the underlying structural causes of conflict, often deferring the resolution of structural causes to subsequent governments (Le Van 2011:45). As many conflicts originate in specific areas, conflict causes will therefore also often pertain to certain regions or localities. Yet, local grievances and access to local (political or economic) opportunities are largely ignored by national peace accords. Therefore it is reasonable to expect that the conflict will resume again.

Second, the negligence of local causes of conflict also implies the neglect of local actors and their interests. A growing body of literature has criticised the statist, blueprint-like machinery of top-down peace-building for its propensity to pay insufficient attention to local politics, in the process inhibiting the emergence of a self-sustaining peace (Richmond 2009a, 2009b; Autesserre 2010; MacGinty 2010). This scholarship is relevant for our research by emphasising that 'the local' is not simply at the receiving end of a peace negotiated elsewhere. On the contrary, it is argued that 'the local' has considerable agency to derail, reframe or otherwise influence peace building.

Third, to have broadly pacifying effects, an elite bargain presumes a top-down process implemented by relatively cohesive organisations. However, most conflict actors have roots in particular regions and among particular constituencies with distinct local concerns (see Manning 2004, 2007; Curtis \& De Zeeuw 2010). Hierarchies and command structures are often contested, resulting in a possible disconnect between the national and local level. There is ample evidence that political formations in contemporary Africa, particularly insurgencies, lack organisational cohesion and are prone to defections, fragmentation and factionalism (Bøås \& Dunn 2007; Weinstein 2007; Schlichte 2009; Reno 2011; Cunningham et al. 2012).

In summary, what is missing from existing studies to date is an analysis of whether and how agreements are translated to or adapted at the subnational level beyond the confines of central government institutions, an instrument we define as local power-sharing. It is also not understood whether and to what extent local actors and local concerns are taken into consideration in elite-based negotiations, an inclusion we refer to as local content.

There are at least two ways in which local content in power-sharing agreements may address the sub-national level. First, either local concerns or actors can be included, i.e. powerful local actors are either 
directly involved in power-sharing negotiations or later in the process of implementation. Alternatively, elites involved in power-sharing can identify and address specific local concerns and grievances, either in the negotiation phase or subsequently in the transitional government. Second, power-sharing can be taken to the sub-national level. There are two distinct ways for this 'local power-sharing' to occur. Either a national peace agreement is replicated at the local level, thereby reproducing power-sharing formulas locally between two or more formerly conflicting parties. This can concern political, military and economic positions that are both shared nationally and at the local level. Alternatively, local power-sharing may mean that territories are divided among different actors. This often amounts to maintaining the war-time status quo (Jarstad \& Nilsson 2008: 211). Such an acknowledgement of local monopolies of power (as opposed to a local balancing when power is shared among different factions) can erase a security dilemma for rebel groups, encouraging them to put down arms. In the remainder of this article we distinguish between local balances of power and the juxtaposition of local monopolies of power as two forms of local powersharing.

We are interested in the empirically observable manifestations of power-sharing agreements outside of the political centre, on the subnational level. We essentially pursue two research questions: First, was the local level considered in national power-sharing pacts? Second, what was the impact of the (non-) consideration of the local level on peace?

As Africa is the continent where by far the most power-sharing accords have been signed, we chose to analyse power-sharing processes in three African countries (Liberia, Burundi, DRC) and explore their impact on the local level. These countries share a long history of violent conflict, ended (formally) by power-sharing agreements in the early 2000 . They make interesting country examples for their similarities and differences: historically centralised systems of governance (all three); intense conflict periods (all three); inclusiveness of formal conflict groups in the agreement (all three to varying degrees) and geographical sizes (tiny Liberia and Burundi versus DRC). Moreover, as we show, the agreements vary between a high level of local power-sharing (DRC) to some degree of local power-sharing (Burundi) and finally to none at all (Liberia). This illustrates the importance of contextualisation when considering the importance of the local in peace agreements.

Our methodological approach assumes that power-sharing among national elites may have diverse consequences that belie simple dichotomous assessments (peace vs. continued armed conflict). The ultimate 
test for the effectiveness of power-sharing agreements are those areas and regions that were heavily affected by violence, prior to a peace agreement. If these 'former' hotspots of conflict remain violent, the very objective of a peace accord remains elusive. We conducted extensive fieldwork in six local arenas (two in each country) to investigate the pacifying effect of power-sharing on the local level, looking for local arrangements and adaptations that may account for divergent outcomes. The findings are based on a total of 172 individual semistructured interviews as well as 21 focus group discussions (FDGs) conducted in Liberia, Burundi and the DRC between June and December 2011.

The six case studies (local arenas) are Gbarnga and Ganta (Liberia), Gitega and Bubanza (Burundi), and Goma/Sake and Bukavu/Kalehe (DRC). ${ }^{1}$ These localities exhibit important differences in their conflict history and dynamics as well as popular perceptions of 'peace'. In fact, we found that peace can mean very different things to different people. Therefore we are reluctant to formulate a one-fits-all operationalisation of our dependent variable (local peacefulness). Instead we use context-specific indicators for each case, inductively derived from our empirical research. It is important to emphasise that we place a modest standard on the expected pacifying effects of power-sharing since we focus on relatively short transitional power-sharing processes. We used the same methods (FGDs and interviews) with roughly the same - contextually adapted - guidelines and chose interviewees with a similar background (market women, youth and teachers for the FGDs, local political, administrative, security and civil society elites for individual interviews).

The rest of the paper is organised as follows: in the next section, we present the three country studies. For each one, we will first sketch the trajectory of the peace process and account for the power-sharing content of the peace agreements. Secondly, we will establish the extent and mechanisms through which the national peace and power-sharing process was linked to the local level: considering not only whether local concerns were included, but also to what degree the peace process was explicitly or implicitly, formally or informally, extended to the subnational level. Thirdly, we consider whether peace has consistently returned to both the national level and in the chosen two arenas - and analyse the link between the outcome (peace or persistent armed conflict on the local level) and the degree to which the local level was taken into account in the peace process. We will compare and contrast the results of this analysis in a final section. 
The Liberian civil war formally ended in August 2003, when the government of Liberia (GoL) and two insurgent groups, Liberians United for Reconciliation and Democracy (LURD) and the Movement for Democracy in Liberia (MODEL), signed the Comprehensive Peace Agreement (CPA) in Accra. The CPA stipulated a transitional unity government (2003-2005), based on political power-sharing. This included the cabinet, seats in the transitional Legislative Assembly and other state institutions. Representatives of civil society and political parties (who also signed the agreement) received a limited number of posts. Economic power-sharing consisted mainly in the distribution of directorship of parastatal companies amongst the different factions, which became an important source of accumulation and patronage (Hoffman 2004: 221; Sawyer 2008: 180-1). Military power-sharing was not part of the agreement. Rather than amalgamating all existing groups into a new national army the negotiators agreed to disband all armed factions, before newly vetted army and police units were formed. The implementation of the agreement was assisted by a 15 ,ooo strong UN peacekeeping mission (UNMIL), which began deployment shortly after the CPA was signed.

Liberia has always politically been a highly centralised country. Thus concerns and interests of local power-holders have a tendency to be intertwined with national-level concerns. To this day a perception remains salient, whereby Liberia is divided between its capital Monrovia and the rest of the country, widely referred to as the hinterlands. Grievances concerning land tenure, lack of infrastructure and unemployment remain pervasive. However, whilst most rebel groups can certainly be associated with specific regions of Liberia, they never specifically fought for autonomy of their home regions, but rather for a piece of the national cake. Unsurprisingly, therefore, perceptions of peace at the local level were coupled to national dynamics, not locally bounded conflicts. According to our interlocutors the most important measure of local peace was the demobilisation of rebel groups and the arrival of UNMIL groups. The gradual return of personal security and the normalisation of everyday life were attributed to the national peace process, its dynamics and key players.

\section{Local power-sharing in Liberia}

The sub-national level was barely involved, either during the peace negotiations or the subsequent interim government. In terms of local 
content, neither Ganta nor Gbarnga, our arenas of analysis, were directly represented in the Accra negotiations, neglecting both local actors and their concerns. A number of civil society observers from these arenas participated, though none of them specifically represented their local home area (civil society activist July 2011 int.; NGO director 2011 int.; Kidau 2011 int.). It could be argued that both places were represented to the extent that they counted (and still do) as strongholds of Charles Taylor's National Patriotic Party (NPP). Some interviewees indeed felt that they were represented at the negotiations due to the heavy influence of Taylor (e.g. NGO director 2011 int., Mulbah 2011 int., Howard-Taylor 2011 int.). Nonetheless, these opinions were held by just a few, usually those still politically active with the NPP. Furthermore, the CPA did not expressly target distinct local concerns, such as refugee repatriation or pervasive land conflicts, challenges that would be left to the new government, elected in 2005. Informants in both Ganta and Gbarnga complained about the inaction of the government regarding these concerns. However, it was also suggested that repatriation, resettlement and land issues were nationwide problems; that is, not considered to be specific to Ganta or Gbarnga. This is likely to be related to suppression of political identities and autonomy in the hinterlands during the entire history of the Liberian state (Bøås 2005). By and large, then, interviewees considered the power-sharing pact among elites as a necessary evil.

In terms of local power-sharing, CPA negotiators explicitly decided that power-sharing arrangements would not be extended locally, thus anchoring transition politics firmly in Monrovia. According to the current mayor of Ganta 'the presence of the interim government was not really felt here' (2011 int.). This meant, for example, that local government positions were not re-allocated. Likewise, power-sharing did not involve territorial aspects in the form of decentralization, which could have brought 'the local' back into the peace process. It could be argued however, that some informal power-sharing took place, as the Monrovia-based unity government did not try to remove local officials already present there. Pro-Taylor factions had recaptured Ganta, like much of Nimba County, from LURD in the final days of the war. The local pro-Taylor commander, General Adolphus Dolo, appointed a new mayor, who stayed in office throughout the transition and was only replaced in 2008, by another former associate of Taylor.

These status quo politics, whilst partially a sign of central government weakness, were also a deliberate, albeit informal, sharing of power by attributing the regional monopoly of power to conflict parties. The area 
was left to Taylor associates, while other parts of Liberia-such as Voinjama - were left to associates of the LURD rebels. Given Ganta's reputation as a Taylor stronghold, the incoming transitional government feared that too much interference could destabilise a fragile situation. ${ }^{2}$ In the words of Senior Senator of Bong County, Jewel Howard-Taylor, 'During the interim government there was not really any political decision making at the local level, they were just trying to keep the peace' (2011 int.).

\section{Local peace in Liberia}

From a macro-political perspective, many observers have regarded Liberia's transition process as a success (Harris 2006; Nilsson 2009). To be sure, the transition experienced rampant corruption and it was unable to lay the structural foundations for effective and reformed statehood. In the wake of the first post-war elections, the UN noted the fragility of the security situation, pointing out regional volatility, weak domestic security forces and limited government authority in most parts of Liberia (UN Security Council 2006). Nonetheless, the resumption of large-scale violence was avoided, arguably the key objective of the powersharing transition. Most CPA provisions were implemented and the former enemies basically abided by the peace agreement, permitting peaceful elections in 2005 (Harris 2006; Sawyer 2008) and 2011. It was however due to the presence of UNMIL that further large-scale violence was avoided, rather than the top-down imposition of power-sharing. At the time of writing over 8,ooo uniformed peacekeeping personnel remain in the country; on the national scale the war as such has ended.

How does this situation of fragile peace relate to the local level? Although the local level was at best marginally addressed, both in terms of local content and local power-sharing, the situation in the towns of Ganta and Gbarnga more or less mirrored the overall trend in the country. A tacit form of peace emerged relatively quickly in the wake of the CPA. Whilst the two arenas certainly remain more fragile to this day compared with other parts of Liberia, neither of the two have faced extreme violence since the end of the war either.

In Gbarnga, tensions persisted in the interim period prior to the 2005 elections. Disputes between members of the majority Kpelle and the much smaller Mandingo ethnic group, perceived as supporters of LURD, escalated into riots. It was UNMIL who managed to calm down the situation. Disgruntled foot soldiers, whose commanders were reaping the benefits of power-sharing in Monrovia, continued to loot 
surrounding villages in the aftermath of the CPA. Nevertheless, according to informants tensions abated considerably after the arrival of UNMIL troops as early as December 2003 and the subsequent disarmament process. Much like nationally in Liberia, it was UNMIL that kept the peace after the CPA was signed (see above).

In Ganta a negligible degree of central control was exercised during the interim government period. Power remained with former pro-Taylor commanders who appointed a new mayor and replaced town chiefs with former combatants (see also Munive 2010: 17). As perceived by local residents, day-to-day insecurity continued during the interim period, but the situation gradually improved with the deployment of UNMIL and progress in Disarmament, Demobilisation and Reintegration (DDR). Nonetheless, one major exception came up in all the interviews and focus groups, namely land-related conflict. Whilst this is not unique to Ganta, it is certainly felt more strongly here than in Gbarnga. In a focus group discussion with market women more than two thirds of the group argued that land conflict continues to threaten peace in Ganta to this day. The mayor, appointed by local commanders in 2003, was said to have exacerbated tensions by - at best - turning a blind eye to ex-combatants (primarily from the Gio and Mande group) squatting on land and houses belonging to Mandingo individuals, who had formed the majority within LURD. More generally, the monopoly of pro-Taylor factions in Ganta has reinforced a perception of marginalisation among the Mandingo community (e.g. Mandingo Representative 2011 int.). Ganta makes a case for the lack of local content (land rights) and local power-sharing being a factor in continued conflict. If power-sharing had been replicated here, resulting in local balances of power with the Mandingo group being included, thus potentially giving the resolution of land conflict a fairer chance, the outcome on peace might have been different.

Nevertheless, with the notable exception of land conflict, residents of Ganta feel that (negative) peace has largely returned. The peace has been largely attributed to two factors. First, and only to a certain extent, appeasing the elite's appetite for a share of the cake had an immediate effect throughout the country. Second, and widely argued as more important by our informants, international peacekeepers had a significant impact. On-going local conflicts such as disputes between Kpelle and Mandingo in Gbarnga were forcefully managed thanks to the extraversion of security to UNMIL and international donors. The disarmament of former combatants, including the foot soldiers, is widely seen as being highly correlated with the resumption of local peace. To some extent, therefore, peace was indeed imposed 'from above' - albeit not by central 
government in Monrovia, but by international actors, especially UNMIL. In addition, one important detail was that Charles Taylor, a key player during the wars fled the country, thus decapitating one of the most important fighting factions.

In conclusion therefore, despite the exclusion of the local level (i.e. local content) in the peace agreement and no local power-sharing, peace has resumed in both Gbarnga and Ganta, due to other factors.

\section{B U R U N D I}

The civil war in Burundi that started in 1993 can be characterised as a multilayered conflict with different lines of confrontation. The most obvious one opposed the former government, the Union pour le Progrès National (UPRONA) with its all-Tutsi army, and Hutu rebel groups, eager to gain a share of Burundi's political, economic and military power. In 2000, the Arusha peace agreement was signed by a group of Hutu parties (the 'G7'), under the lead of Front pour la Démocratie au Burundi (FRODEBU) and a group of majority Tutsi parties (the 'G1o'), led by UPRONA. However, it was only in late 2003 that the country's largest insurgent group, the Hutu-dominated Conseil National pour la Défense de la Démocratie-Forces de Défense de la Démocratie (CNDD-FDD) signed a ceasefire, thus joining power-sharing arrangements meant to end over a decade of civil war. A second Hutu insurgent group, the Forces Nationales de Libération (FNL), refused to disarm and only signed a peace accord in 2008.

Burundi is often presented as the most sophisticated and complete case of power-sharing in Africa (Bentley \& Southall 2005; Daley 2007; Falch \& Becker 2008). During the transition (2000-2005) a mixture of political and ethnic power-sharing between Hutu and Tutsi was established. The National Assembly was enlarged in order to include all parties to the Arusha agreement. Ministries were divided up between the G10 and $\mathrm{G}_{7}$ parties, with a strong overrepresentation of the minority Tutsi parties. When the CNDD-FDD joined in, the power-sharing formula was adapted to include the newcomers in the institutions. By the same token, military power-sharing was pursued in the national army, with $40 \%$ of officers now coming from the CNDD-FDD. The peace process was first overseen by South African peacekeepers, later replaced by AU troops, followed in 2004 by a UN peace operation comprised of up to 5,600 blue helmets. However, these troops never had the same strength as in Liberia. 
None of the conflict actors, relatively cohesive organisations with strong hierarchical agency, claimed to defend the rights of the people of a particular territory, but rather those of an ethnic group-groups which have never been spatially segregated. Ordinary Hutu and Tutsi were pitted against each other during the war years, fighting an inter-group conflict, related to both elite manipulation and individual motivations that diverged from place to place (see e.g. Bentley \& Southall 2005; Lemarchand 2009). Ethnic heterogeneity as well as relevant conflict issues such as land scarcity, lack of infrastructure or poverty, were rather evenly distributed throughout the periphery. Therefore dynamics at the sub-national level largely mirrored those at the national level, as in Liberia. Accordingly, in the perception of our informants the most important marker of local peace was the end of inter-ethnic hostilities paired with the re-establishment of normalised everyday life (variously expressed as the re-opening of ethnically mixed schools, being able to go to the fields, going out at night, etc.).

\section{Local power-sharing in Burundi}

Dominated by national elites, Burundi's peace negotiations and agreements hardly exhibited local content. Neither locally defined actors nor locally specific concerns were taken into consideration in the peace process as all issues tackled by the Arusha Agreement had a national character. Only informally - and very marginally - was the territorial administration the object of the negotiations, leading to some basic forms of local power-sharing. Thus, tripartite local governments were common, as for example in Bubanza, where the chief administrator and his two deputy councillors came from different ethnic groups and political parties (Journalists 2011 int.). However, the fact that conflict in Gitega and Bubanza largely mirrored national dynamics meant that tackling ethnic discrimination was both a national as well as a local concern. Generally, genuine local content in national arrangements as well as specifically local power-sharing only became important after the transition, introducing a shift from political power-sharing to ethnic power-sharing. This was partly driven by new laws addressing subnational politics. For example, elected communal councils now have to reflect the ethnic diversity of their commune. Moreover, the new constitution stipulates that governors must hail from the province they administer, as well as establishes a Senate, composed of two locally elected representatives for each province. In provinces like Bubanza, 
historically administered by individuals from the south, these new regulations have enhanced a sense of ownership and representation. ${ }^{3}$

In addition to the formal replication of power-sharing at the local level and minor provisions of devolution, the idea of ethnic power-sharing dominates informal institutions and events at the local level to this day.

\section{Local peace in Burundi}

Given the narrow objectives of the transition, the peace process in Burundi counts as a success. Unity government survived the transition, paving the way for the peaceful 2005 elections, which delivered an outright victory to the CNDD-FDD. Large-scale fighting came to an end once the CNDD-FDD joined the peace process. Conflict in the border region with the DRC (including the province and town of Bubanza) persisted on a lower level as the FNL continued to fight. However the group had lost its political rationale of protecting Hutu interests with the inclusion of the CNDD-FDD in government. In general, the latter was perceived as a victory of the Hutu majority after decades of ethnic discrimination. At the same time, enough protective measures had been offered to prevent UPRONA from derailing the process. Former Tutsi presidents were given seats for lifetime in the senate and measures were taken to guarantee a continuation of privileges - in some cases 'even more privileges than before'-for army officers (civil society activist 2011 int.).

Although no coordinated effort to reconcile the population has been undertaken, inter-ethnic suspicion has decreased. New conflicts are largely fought along political lines, within the Hutu majority, that is between the CNDD-FDD and its political-and partly armed-Hutu opposition. Threats to peace have re-emerged in recent years, with the state becoming a de facto (multi-ethnic) one-party state under the control of the CNDD-FDD and growing political violence in all parts of the country. Growing authoritarian tendencies of the dominant party and its lack of tolerance of political opposition are beginning to supplant encouraging beginnings of the peace process.

Gitega and Bubanza, major hotspots during the civil war, both closely mirrored the political situation on the national level. In Gitega, the accession of CNDD-FDD to the peace agreement was felt immediately, leading to an end of violence almost overnight. War-time ethnic segregation was abandoned and improvements in the cohabitation of Hutu and Tutsi were visible almost at once. Many interviewees and focus groups mentioned the end of the 'balkanisation' of Gitega as a sign of 
peace, using a term that is often used in the region (including in neighbouring DRC) to describe ethnic (or political) segregation of territory.

In Bubanza, insecurity and violence persisted even after the accession of the CNDD-FDD to the peace deal, due to the ongoing insurgency of the FNL. In the local perception, the worst fighting was over once the CNDD-FDD had joined the peace process, as this meant an end to the generalised discrimination of Hutu. This was confirmed by a transition senator, who acknowledged however that this impression might be at least partly due to the CNDD-FDD's propaganda, though the CNDD-FDD did largely secure the area after 2004 (2011, int.). A former FRODEBU administrator of Bubanza concurred, noting: 'the FNL continued the armed struggle, but the worst was over in 2004/05' (Bigimana 2011 int.).

Local power-relations in Gitega and Bubanza changed in their essence - in the sense that power was now shared between Hutu and Tutsi-but not so much 'in persona'. Most former administrative personnel had been killed, exiled, or held office only for a short period of time and many functions had been taken over by the army during the conflict years. Thus, the new administrative power-holders in Gitega faced little contestation, as they entered almost an administrational vacuum. As the FNL was still active in Bubanza and has a strong base there to this day, power-struggles between CNDD-FDD and FNL soon became the norm, one reason why the area remains tense to this day.

As shown, local actors were hardly involved in the negotiations, which were dominated by national political and military elites. However, the idea of ethnic power-sharing soon started penetrating all levels of the polity, including Gitega and Bubanza, for several reasons.

First, although Burundi's political history has been deeply influenced by a strong regional bias favouring its southern part, the country's social structures imply that political actors, including the rebellions, are not primarily associated with specific regions and localities. Similarly to Liberia, this in a sense pre-empts spatial-regional factors to influence political dynamics. Local cleavages generally tend to mirror cleavages on a national level. From 2000 onwards, the main structural cause of the conflict-ethnic discrimination - was extensively addressed. The transformation of the army - the main means of oppression during decades of Tutsi rule-into a multi-ethnic institution appeased the situation throughout the country. Transforming the Hutu-Tutsi cleavage was possible without specifically considering the local level from the outset. Once the idea of power-sharing had gained traction among elites, it soon trickled down to the most local level, arguably having a very positive 
effect on the cohabitation of Hutu and Tutsi in both Gitega and Bubanza.

Second, Burundi historically exhibits a strong culture of political centralisation. Political organisations traditionally have strong hierarchies. This of course does not mean that there are no splits within given movements. After all, the CNDD-FDD was a splinter group of FRODEBU and further split into the CNDD and the CNDD-FDD during the peace talks. After 2005 the CNDD-FDD experienced further splits - at times regionally motivated (Nindorera 2012). However, these dynamics were not caused by the exclusion of certain localities from the peace talks or government institutions. Rather, different factions split over whether moderate or radical demands and actions were better suited to succeed and disagreed on key issues, mostly concerning details of army integration (see Bentley \& Southall 2005: 105).

The limited extent of local power-sharing did not really influence these dynamics, questioning the claim that peace cannot be imposed from above. In the cases where local power-sharing had been imposed by the national elites it has worked rather smoothly.

In summary, local peace in Burundi, as in Liberia, seems to have been the product of national power-sharing-most importantly the creation of a multi-ethnic army-as well as a number of related factors. They include the magnetic attraction of the CNDD-FDD for other Hutu (and Tutsi) elites once the group joined the process, the CNDD-FDD's near certainty to win the elections, and trust in Tutsi elites, or their inability to undermine the peace process due to strong international/regional pressure. What is important in the Burundian case however is that due to the centralised nature of the state and the even distribution of ethnic heterogeneity as well as the similarity of grievances across the country, 'local' and 'national' tend to blur when it comes to conflict management. This is in stark contrast to the DRC, as we will show in the next section.

DEM OCRATIC REP U B L I C F C O N G O

Intertwined armed conflicts have raged in the DRC since the mid-1990s (e.g. Tull \& Mehler 2005; Prunier 2011). Since 1998, the war primarily pitted the government against the rebel group Rassemblement Congolais pour la Démocratie (RCD), largely (but not exclusively) associated with Rwanda and the Rwandophone ethnic communities in North and South Kivu. Apart from the RCD a plethora of other armed groups emerged during the war claiming to represent different constituencies and 
forming complex and sometimes counter-intuitive alliances with each other.

Only in 2003, after four years of negotiations, and parallel agreements with Rwanda and Uganda, did the regional war officially end. A peace accord with a far-reaching system of transitional power-sharing was signed by President Kabila and the main rebel groups, RCD, Mouvement de Libération du Congo (MLC) and RCD-Mouvement de Libération (RCD-ML). ${ }^{4}$ The power-sharing provisions covered political, military, and economic dimensions. The presidency was shared between Kabila and four vice-presidents from the RCD, MLC and political opposition. Similar rules were applied to the National Assembly and the (newly created) Senate, a number of other transitional institutions, parastatal companies (i.e. economic power-sharing) and the army (i.e. military power-sharing). It was a finely tuned architecture to maintain a balance of power. Ministers and Deputy Ministers never came from the same faction.

\section{Local power-sharing in DRC}

Amongst the three countries studied, the peace process in DRC included by far the highest degree of 'local content', with the specific inclusion of local actors and concerns as well as a replication of powersharing at the local level. This comes as no surprise, as the DRC is the biggest and most diverse in terms of geography and population. Given the fact that the war in DRC has always had a very strong territorial (regional as well as local) component, power-sharing at the national level almost inevitably included local content. Although the groups that took part in the talks have to be considered as national elites, they also had local roots that cannot be divorced from their political interests and strategies. The transition and power-sharing process at the national level also took account of important sub-national concerns. This included the Congolese citizenship of the Rwandophone minorities in the Kivu provinces (Banyarwanda), a very specific local issue that was put forward by the RCD insurgency, given the Rwandophone origins of many of its leaders and followers. This led to a new inclusive citizenship law to accommodate the Banyarwanda. A second topic with strong sub-national ramifications was decentralisation. During the negotiations of the transitional government for a new constitution, adopted by popular referendum before the end of the transition in late 2005, the RCD advocated the introduction of federalism as a remedy for the country's longstanding and defunct centralised political system (Le Potentiel 2005). 
Although federalism was not adopted, bargaining resulted (de jure) in a strongly decentralised political system.

National power-sharing, as stipulated by the peace agreement, was replicated on the sub-national level in each province. Important posts in the administration and security sector were to be filled by a triad of conflict actors. Governors, local administrators and provincial representatives of national institutions, including police and army, were all subject to this sophisticated power-sharing scheme. All locally relevant figures were thus somehow accommodated. This is important, as we would assume that accommodation prevents the emergence of splits amongst local elites.

In contrast to neighbouring Burundi, both actors and conflict concerns were very much territorially differentiated. The interests of local actors in North and South Kivu were manifold and included both the protection of economic interests and their ethnic constituencies, to name just a few. The heavy involvement of external actors (mainly Rwanda and Uganda as well as international business elites) furthermore complicates the picture. Given the sheer size of the country and its (human-) geographical heterogeneity, the interests of powerful local actors depended on the control of specific territories. The local therefore had very different implications in the Congolese peace process than in Burundi and Liberia.

\section{Local peace in DRC}

On the national level, the peace agreement quickly yielded positive results. Organised fighting largely ended and the conflict parties took up their positions in the central government and other state institutions. Virtually all informants mentioned the reunification of the countryhitherto divided among the warring factions - and the resulting freedom of movement as a major achievement of the peace agreement. The first democratic elections since 1965 took place peacefully and orderly in 2006, marking the end to the transition. The largest UN peacekeeping mission worldwide accompanied the peace process and transition with around 17,000 personnel. Despite the large size of the mission, it has remained largely ineffective in securing the peace in the region.

In the wake of the power-sharing agreement, peace did not unfold in a uniform fashion across the entire territory of the DRC. The provinces of North and South Kivu, where the war had originated, remained zones of pervasive insecurity and violence, including our units of analysis, Goma and Sake (North Kivu) and Bukavu and Kalehe (South Kivu). 
Sake has often been under cross-fire from government soldiers and the various rebel movements. This most recently became apparent during the rebellion of the M23, an offshoot of the Conseil National pour la Défense du Peuple (CNDP). Starting in the spring 2012, it briefly seized control of Goma and Sake.

Kalehe, just as Bukavu, saw severe fighting between government troops, the RCD and Rwandan insurgents of the Forces Démocratique de Libération du Rwanda (FDLR) and the Mai-Mai militias throughout the war. Despite experiencing heavy violence in many parts of North and South Kivu - including Sake and Kalehe - the situation improved to one of relative calm, in the final days of the war.

In both arenas however, armed fighting resumed during or in the immediate aftermath of the transition. In Kalehe, heavy fighting erupted in 2004 during the so-called 'war of Bukavu' when hundreds of people were displaced, raped and killed in a matter of few weeks. The war was fought between the army and a breakaway faction of the RCD, later to be renamed CNDP, led by Laurent Nkunda. Nkunda had been offered several posts in Kinshasa during the peace process, but decided to stay in the Kivus to safeguard the RCD's local power monopoly. The other faction of the RCD, led by Azarias Ruberwa, took up posts in the unity government, with Ruberwa becoming Congo's Vice-President. Thus, the mere inclusion of local actors, such as the RCD leadership around its then President Ruberwa, is no guarantee for local peace. In fact such inclusion rests on the assumption of a high degree of cohesiveness of any given insurgent group. However, the DRC case shows that this is by no means always the case.

Kalehe was at that time occupied by Nkunda's troops, causing new violent clashes with the Mai-Mai militia and the government army. After a few months, the CNDP retreated to North Kivu, were it effectively established a 'state within a state'.

During this time, a frontline between the CNDP and the government troops also directly ran through Sake. People in Sake stated that things only got better after 2009, when a peace agreement between Kabila and the CNDP ended the fighting, de facto again granting the rebels an unofficial monopoly. Most interviewees and all focus groups agree that the peripheries surrounding Sake were not really secured: 'Sake town is safe, but there is war in the hills' (Local Government Official 2011 int.). The same is true for Kalehe, where respondents mainly mentioned the Rwandan FDLR militia as a threat. These very tangible threats - killings, lootings, harassment, rape-paired with a feeling of being constantly governed by 'foreigners' were the indicators for non-peacefulness given 
by the non-Tutsi community in both Sake and Kalehe. In fact, peacefulness has a very particular connotation for the communities in those areas where actual fighting among conflict actors and against the civilian population has been linked to struggles for the monopoly over territory and local resources. The calm following the monopolisation of power by one particular actor never meant peace for all, but only for some.

How are these dynamics related to the local implementation of powersharing? The elaborate local power-sharing formula in DRC met an uneven fate in practice. In North Kivu, the RCD effectively worked to undermine the scheme, keeping almost exclusive control over all posts and levers of power. Officials sent from the Kabila faction were not able to work effectively, sometimes denied access to offices and information or were killed (Journalist 2011 , int.; Researcher 2011 , int.). The posts of governor as well as the regional military commander were retained by the RCD, and their second-in-commands were not able to effectively counterbalance their power. This informal, de facto monopolist situation became official when President Kabila confirmed Eugène Serufuli as governor of North Kivu, a position the RCD heavyweight had occupied since 2000. According to many observers in Goma, Kabila had little choice but to accept the RCD's power in the region (Researcher 2011, int.; Journalist 2011, int.). North Kivu was kept under RCD control and until the end of the transition things remained relatively calm in the run-up to the 2006 elections. The RCD, now a political party, received a beating at the polls, especially in the areas it had controlled since 1998, effectively ending its political life. Led by Nkunda, parts of the RCD responded with a renewed rebellion (the CNDP), taking control over large areas of North Kivu.

In South Kivu, the RCD was far less entrenched, meeting significant local resistance. Initially, some degree of power-sharing took place on political, administrative and military levels in the province. The uneasy coexistence between representatives of the RCD and (primarily) Kabila loyalists collapsed in May 2004 when rival army units clashed in Bukavu. The episode and its consequences nearly led to the breakdown of unity government in Kinshasa (Tull 2004). In the aftermath of this crisis, power-sharing was effectively terminated in South Kivu as the RCD was forced to leave the province to Kabila's allies. Those RCD elements that remained in South Kivu kept a low profile, effectively bending to the will of the Kabila dominated majority. Many cadres left the movement (Journalist Bukavu 201 1, int.).

In summary, the situation in North and South Kivu during the transition was in contradiction to the national power-sharing accord. 
Both provinces were under the control of a monopolist, with the RCD in charge of the former and the Kabila faction of the latter. After initial power struggles until mid-2004, monopolist control had a somewhat pacifying effect on both provinces, at least until the end of the transition in late 2006. Fighting broke out again when this monopoly was threatened after the elections in 2006.

Thus power-sharing in DRC yields unexpected consequences. The CNDP emerged as a challenger to the supposed peace in North Kivu, despite significant offers of inclusion for its leaders in the national peace deal. Alleged political grievances such as citizenship concerns were addressed in the peace agreement. This did not however lead to local peace. In fact, it seems that these concerns-albeit important for the local population - were not determinant for rebel elites, or at least that motivations had changed over time. Control over resources-economic and political - remains at the heart of this conflict. Local power-sharing threatened the monopoly over resources of one of the most important conflict actors, Rwandophone networks of elites, and thus had no chance to survive. When in 2012 the informal monopoly of the CNDP was again threatened, the M23 rebellion emerged.

\section{A N A LYS IS}

A close look at six sub-national arenas in three major war zones in Africa reveals that the political trajectory of these former violent hotspots largely mirrors the overall trend on the national level, at least in the immediate post-agreement period. The positive trend of national peace, illustrated by the formation of unity government and the absence of organised fighting, was not decoupled on the local level in four of six cases.

Looking at the empirical sub-national record in Liberia and Burundi, national power-sharing (which had provided ample incentives for elites), directly or indirectly, had a positive impact on local peace and security, despite the fact that power-sharing was not significantly and formally extended to the local level. One explanation might be the (lack of) spatial-regional political dominance of any of the conflict parties, most clearly the case in Burundi. In Liberia, despite stronger spatialregional dominance, this was never the goal of the conflict parties. Furthermore, centuries of centralisation policies no doubt also played a role. In Burundi, the transformation of ethnic grievances at the national level was positively mirrored locally. In Liberia, the power-sharing formula managed to appease the conflict parties' quest for power. 
As numerous interviews and focus groups discussions made clear, almost without exception, the sharp reduction or even absence of violence was positive and promising, but the situation remains fragile. These countries undoubtedly experience 'negative peace', to paraphrase Galtung (1964), describing merely the absence of violence. Unresolved structural problems remain. The fact that local concerns and actors were generally excluded could yet negatively affect the transformation of these countries in the coming years.

We conclude that elite-based power-sharing as a broad formula was instrumental in sharply reducing violence in these cases and instigating a de-militarisation of political conflict, even though at considerable costs (no reconciliation, impunity etc.). Power-sharing was only one, but an important part of the story. Numerous other factors certainly played a role in support of the process, which we have not the space to analyse fully here, including the small size of Burundi and Liberia, combined with the relatively large size of peacekeeping troops (especially in Liberia).

The difference between the types of local power-sharing, whether reproducing the same power balances as on the level of the national state, or establishing monopolies by one group are significant. In Burundi, the former had a positive influence on peace, especially in the post-interim period. In Ganta, Liberia, the status quo arrangements maintained the monopoly of power by pro-Taylor factions. This has arguably led to pervasive low-intensity land conflict, due to a lack of local power-balance.

In DRC, de facto monopolies of power on the local level and in various regions seem to have contributed to some kind of fragile peace, although it is very differently perceived among local communities. Nonetheless, every time a local monopoly was threatened, renewed fighting broke out. This was the case in 2004, in 2006 and in 2012.

Overall, we have found little confirmation for the view that promoting power-sharing to achieve peace requires its extension or reproduction on the sub-national level. This can be explained with respect to Burundi and Liberia, small and centralised countries with relatively cohesive conflict actors, where the boundaries between 'local' and 'national' dimensions are blurred. Exclusive national power-sharing may work relatively effectively despite - or perhaps because of - the fact that it is limited to national elites in capital cities, at least in the short term. In both Burundi and Liberia, the fact that no local power-sharing evolved from the respective peace processes, nor included much local content, did not seem to have a overtly negative impact in the short-run. In 
contrast, in the large and heterogeneous DRC, local concerns and actors were included. Local forms of power-sharing were stipulated by the peace process, but they were either too contested, thus pre-empting implementation (Sake/North-Kivu), or led to renewed violence (South Kivu/Kalehe).

These conclusions run counter to the often-made claim that the local level needs to be taken into account to build peace. Our findings suggest that local political actors have far less political autonomy than recent scholarship on local peace-building suggests in small and historically highly centralised states such as Burundi, where national elites exert a strong grip over local politics - at least in the face of short-term transition periods. Broken links between the political centre and local arenas as a result of years of violent conflict, where entire regions either escaped the control of the political centre or where central authority was simply limited (as can be seen in the DRC) is a different matter. Liberia shows how a robust international military presence can successfully suppress renewed armed conflict at the local level despite the absence of central (national) authorities.

Generally, our cases lead us to reconsider the idea of local conflict causes. We have seen that the accommodation of elite interests was conducive to peace in Liberia despite the exclusion of pressing concerns such as unemployment and land conflict. These were however seen as national grievances, not local ones. In Burundi, the main interest of the conflict parties - access to power for one and the securing of power for the other-was somewhat congruent with the solution of the major cause of the conflict, namely ending ethnic discrimination. In the DRC the tackling of conflict concerns specific to particular localities - such as the citizenship question - was not sufficient to bring peace. The main interest of powerful local actors in North and South Kivu was, and remains, not so much the tackling of structural problems or access to national institutions, but their monopoly over the area-which is threatened rather than secured by local power-sharing. Our cases thus suggest, first, that the 'local' in 'local concerns' can mean very different things. Whereas local concerns were similar throughout the country in Liberia and Burundi, they were very much bound to specific territories in the DRC. Second, the inclusion of local conflict actors and concerns in national peace agreements does not in itself constitute a guarantee for peace at the local level. Local concerns (or grievances) are often just a mobilising factor at the hand of local elites. And the inclusion of local elites in national negotiations may not solve conflicts effectively as those elites are by no means uncontested locally or else are not able to rein in 
rival elites in the conflict zones. The case of DRC leads us to a third conclusion: we have to clearly distinguish between local power-balance in the sense of a reproduction of the national power-sharing at the local level and the granting of local power-monopolies as a second form of power-sharing. The latter has partly appeased the situation during rather brief periods, whereas the former had negative effects in both North and South Kivu during the transition. Thus one could argue that more and not less power-sharing was necessary in the DRC-albeit in the form of a local monopoly. But even this arrangement remained fragile and has pre-empted renewed fighting only in the medium term. The results presented thus far derive from our research in three African countries, but it would of course be desirable and necessary to examine more cases of local power-sharing, in Africa and elsewhere, in order to evaluate the validity of our analysis.

Peacebuilding efforts at the local level tend to be romanticised as almost necessarily peace-enhancing. The Congolese example shows how the introduction of local power-sharing can actually lead to renewed conflict instead of ameliorating the situation. The local balancing of power, observed in post-transition Burundi, may improve matters, but this is not necessarily so, as the DRC painfully underlines. Context plays a crucial role. Generally, the three countries under consideration suggest that the generalised use of the term 'local' is problematic. Local content as well as local power-sharing meant very different things in each case. Issues that may in fact need to be considered are the history of spatialpolitical links, the centralised politics of caring about the periphery as well as the establishment of local balances or monopolies of power.

\section{NOTES}

1. For details on our case selection see Simons \& Zanker (2012).

2. In some areas, fighters did not really play an important role, thus status quo arrangements can be traced to the weakness of the interim government.

3. All three focus groups and most interviewees in Bubanza stressed this as a major improvement.

4. Mai-Mai militias, civil society groups and political parties also signed but had much less agency during the negotiations as well as in the subsequent institutions than the armed conflict parties.

\section{R E F E R E N C E S}

Autesserre, S. 2010. The Trouble with the Congo. Local violence and the failure of international peacebuilding. Cambridge: Cambridge University Press.

Bentley, K.A. \& R. Southall 2005. An African Peace Process: Mandela, South Africa and Burundi. Cambridge: Cambridge University Press.

Bøås, M. 2005. 'The Liberian civil war: new war/old war?', Global Society 19, 1: 73-88.

Bøås, M. \& K.C. Dunn. 2007. African Guerrillas: Raging Against the Machine. Boulder, CO: Lynne Rienner Publishers. 
Cunningham, K.G., K.M. Bakke \& L.J.M. Seymour. 201 2. 'Shirts today, skins tomorrow: dual contests and the effects of fragmentation in self-determination disputes', Journal of Conflict Resolution $5^{6,1}$ : $67-93$.

Curtis, D. \& J. De Zeeuw. 2010. Rebel Movements and Political Party Development in PostConflict Societies - A Short Literature Review. New York, NY: Ralph Bunche Institute for International Studies.

Daley, P. 2007. 'The Burundi peace negotiations: an African experience of peace-making', Review of African Political Economy 34, $112: 333-5^{2}$.

Falch, Å. \& M. Becker. 2008. Power-sharing and Peacebuilding in Burundi. Oslo: PRIO.

Fearon, J.D. \& D.D. Laitin. 2003. 'Ethnicity, insurgency, and civil war', American Political Science Review $97,1: 75^{-90 .}$

Galtung, J. 1964. 'An Editorial', Journal of Peace Research, 1, 1: 1-4.

Harris, D. 2006. 'Liberia 2005: an unusual African post-conflict election', Journal of Modern African Studies 44, 3: 375-95.

Hartzell, C. \& M. Hoddie. 2003. 'Institutionalizing peace: power sharing and post civil war conflict management', American Journal of Political Science 47, 2: $318-32$.

Hoddie, M. \& C. Hartzell. 2005. 'Power sharing in peace settlements: initiating the transition from civil war', in P.G. Roeder \& D. Rothchild, eds. Sustainable Peace: Power and Democracy after Civil Wars. Ithaca, NY: Cornell University Press, 83-106.

Hartzell, C. \& M. Hoddie. 2007. Crafting Peace: Power-Sharing Institutions and the Negotiated Settlement of Civil Wars. University Park, PA: Pennsylvania State University Press.

Hoffman, D. 2004. 'The civilian target in Sierra Leone and Liberia: political power, military strategy, and humanitarian intervention', African Affairs 103, 411: $211-26$.

Jarstad, A.K. \& D. Nilsson. 2008. 'From words to deeds: the implementation of power-sharing pacts in peace accords', Conflict Management and Peace Science 25, 3: 206-23.

Lake, D.A. \& D. Rothchild. 2005. 'Territorial decentralization and civil war settlements', in P.G. Roeder \& D. Rothchild, eds. Sustainable Peace: Power and Democracy after Civil Wars. Ithaca, NY: Cornell University Press, 109-32.

Le Potentiel. 2005. Partisan Du Fédéralisme: Le RCD Menace De Bloquer La Constitution.

Lemarchand, R. 2007. 'Consociationalism and power sharing in Africa: Rwanda, Burundi, and the Democratic Republic of the Congo', African Affairs 106, 422: 1-20.

Lemarchand, R. 2009. The Dynamics of Violence in Central Africa. Philadelphia, PA: University of Pennsylvania Press.

MacGinty, R. 2010. 'Hybrid peace: the interaction between top-down and bottom-up peace', Security Dialogue 41, 4: 391-412.

Manning, C. 2004. 'Armed opposition groups into political parties: comparing Bosnia, Kosovo, and Mozambique', Studies in Comparative International Development 39, 1: 54-76.

Manning, C. 2007. 'Party-building on the heels of war: El Salvador, Bosnia, Kosovo and Mozambique', Democratisation 14, 2: 253-72.

Mehler, A. 2009. 'Peace and power sharing in Africa: a not so obvious relationship', African Affairs', 108, $432: 453-73$.

Munive, J. 2010. 'Ex-Combatants, Returnees, Land and Conflict in Liberia'. Copenhagen: Danish Institute for International Studies, Working Paper.

Nilsson, D. 2009. Crafting a Secure Peace: Evaluating Liberia's Comprehensive Peace Agreement 2003. Uppsala: Uppsala University.

Nindorera, W. 2012. 'The CNDD-FDD in Burundi: The path from armed to political struggle'. Berlin: Berghof Foundation.

Pearson, F.S., M. Olson Lounsbery, S. Walker \& S. Mann. 2oo6. 'Rethinking models of civil war settlement', International Interactions 32, 2: 109-28.

Prunier, G. 2011. Africa's World War: Congo, the Rwandan Genocide, and the Making of a Continental Catastrophe. Oxford: Oxford University Press.

Reno, W. 201 1. Warfare in Independent Africa. Cambridge: Cambridge University Press.

Richmond, O.P. 20oga. 'A post-liberal peace: Eirenism and the everyday', Review of International Studies 35, 3: 557-80.

Richmond, O.P. 2oogb. 'Becoming liberal, unbecoming liberalism: liberal-local hybridity via the everyday as a response to the paradoxes of liberal peacebuilding', Journal of Intervention and Statebuilding 3, 3: 324-44.

Roeder, P.G. \& D. Rothchild. 2005. Sustainable Peace: Power and Democracy after Civil Wars. Ithaca, NY: Cornell University Press. 
Sawyer, A. 2008. 'Emerging patterns in liberia's post-conflict politics: observations from the 2005 elections', African Affairs 107, 427: 177-99.

Schlichte, K. 2009. In The Shadow of Violence: The Politics of Armed Groups. Frankfurt: Campus Verlag.

Simons, C. \& F. Zanker. 2012. 'Finding The Cases That Fit: methodological challenges in peace research'. Hamburg: German Institute of Global and Area Studies, Working Paper.

Sriram, C.L. 2008. Peace as Governance: Power-Sharing, Armed Groups and Contemporary Peace Negotiations. Basingstoke: Palgrave Macmillan.

Tull, D.M. 2004. 'Congo Facing a Third War? Possible Repercussions of the Gatumba Massacre'. Berlin: Stiftung Wissenschaft und Politik.

Tull, D.M. \& A. Mehler. 2005. The hidden costs of power-sharing: reproducing insurgent violence in Africa', African Affairs 104, 416: $375^{-98}$.

UN Security Council (UNSC). 2006. Tenth Progress Report of The Secretary-General On The United Nations Mission in Liberia. New York, NY: UNSC.

Le Van, C. 2011 . 'Power sharing and inclusive politics in Africa's uncertain democracies', Governance $24,1: 31-53$.

Weinstein, J.M. 2007. Inside Rebellion: the politics of insurgent violence. Cambridge: Cambridge University Press.

Williams, P.D. 2011. War and Conflict in Africa. Cambridge: Polity.

\section{Interviews}

\section{B U R U N D I}

Journalists from Radio Publique Africaine, Radio Sans Frontières Bonesha, Agence Burundaise de Presse, Bubanza, 24.11.2011.

Civil Society Activist, Bujumbura, 9.12.201 1.

Louis Bigimana, Administrator of Bubanza 2002-2004, Bujumbura, 5.12.2011.

Senator from Bubanza in the Transitional Government, Bujumbura, 11.12.2011.

D R C

Local Government Official, Sake, 21.7.2011.

Journalist, Radio Okapi, Goma 13.7.2011.

Researcher, Pole Institute, Goma, 25.8.2011.

Journalist, Radio Okapi, Bukavu, 9.8.2011.

Civil Society Activist, Goma, 12.7.2011.

\section{I B E R I A}

Civil Society Activist, Gbarnga, 28.6.2011.

NGO Director, Gbarnga, 1.7.2011.

Head of Native Affairs in Bong County, Gbarnga, 2.7.2011.

George Mulbah, Parliamentary Representative, Gbarnga, 03.7.201 1.

Civil Society Activist, Gbarnga, 4.7.2011.

Nohn Rebecca Kidau, Civil Society member at the CPA negotiations and former Representative

Ganta (2005-11), Ganta, 17.7.2011.

Dorr Cooper, Mayor of Ganta (2008-), Ganta, 19.7.2011.

Mandingo Representative, Ganta, 25.7.201 1.

Jewel Howard-Taylor, Senior Senator Bong County, Monrovia, 4.8.2011. 